\title{
Publisher Correction: An expression atlas of variant ionotropic glutamate receptors identifies a molecular basis of carbonation sensing
}

Juan Antonio Sánchez-Alcañiz, Ana Florencia Silbering, Vincent Croset, Giovanna Zappia, Anantha Krishna Sivasubramaniam, Liliane Abuin, Saumya Yashmohini Sahai, Daniel Münch, Kathrin Steck, Thomas O. Auer, Steeve Cruchet, G. Larisa Neagu-Maier, Simon G. Sprecher (1D, Carlos Ribeiro (D), Nilay Yapici (1) \& Richard Benton (D)

Correction to: Nature Communications https://doi.org/10.1038/s41467-018-06453-1, published online 12 October 2018.

The original version of this Article incorrectly omitted the received/accepted dates of Received: 08 March 2018; Accepted: 06 September 2018. This has now been corrected in the PDF and HTML versions of the Article.

Published online: 25 February 2020

\footnotetext{
(c) Open Access This article is licensed under a Creative Commons Attribution 4.0 International License, which permits use, sharing, adaptation, distribution and reproduction in any medium or format, as long as you give appropriate credit to the original author(s) and the source, provide a link to the Creative Commons license, and indicate if changes were made. The images or other third party material in this article are included in the article's Creative Commons license, unless indicated otherwise in a credit line to the material. If material is not included in the article's Creative Commons license and your intended use is not permitted by statutory regulation or exceeds the permitted use, you will need to obtain permission directly from the copyright holder. To view a copy of this license, visit http://creativecommons.org/licenses/by/4.0/.
}

(C) The Author(s) 2020 